\title{
FOXC2 wt Allele
}

National Cancer Institute

\section{Source}

National Cancer Institute. FOXC2 wt Allele. NCI Thesaurus. Code C52877.

Human FOXC2 wild-type allele is located within 16q22-16q24 and is approximately $2 \mathrm{~kb}$ in length. This allele, which encodes forkhead box protein $\mathrm{C} 2$, is involved in the modulation of transcription by RNA polymerase II. 